\title{
HARVEST OF HOPE
}

\section{An economist believes that a five-year aid effort in a dozen villages across Africa can teach the world how to defeat poverty. Sarah Tomlin reports on the project's progress in Rwanda.}

Hyacinthe Mukaritaganda of Kagenge village helped build a communal water tank, aspart of the Millennium Villages project.

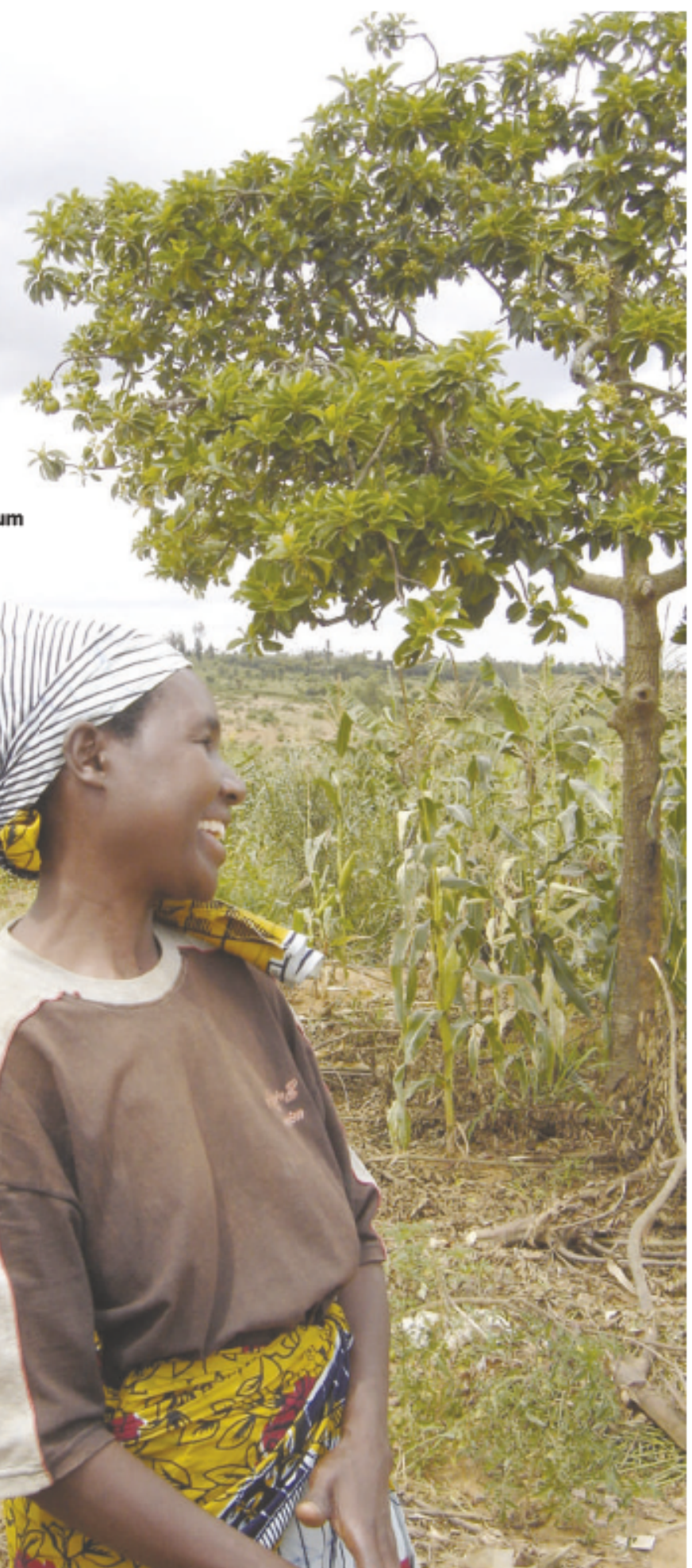

( elestin Ndahayo smiles broadly at me from below the corn (maize) that towers a metre or more above him, his daughter Annalita clutching his hand. This is the first corn harvest he has seen here in almost ten years. There was a smaller harvest of beans and sorghum in 2001; last year there was nothing. In the years without good rains, the people of Kagenge (sometimes called Mayange) in Rwanda survive the best they can. Some walk four nights and three days to reach a more productive region. Ndahayo sometimes takes construction jobs to support his wife and four children.

Hyacinthe Mukaritaganda's husband is one of those currently working elsewhere, leaving her to manage their land and look after three children on her own. This season she planted corn on one-fifth of their land, a short walk from Ndahayo's homestead. Thanks to the rains, she is expecting a good harvest, which should provide enough seeds to plant all 2.5 hectares next year. Then, she hopes, her husband will stay at home to help.

The rains, though, are not the only things bringing hope to Kagenge. In 2005, the village was chosen to take part in the Millennium Villages project. Led by the Earth Institute at Columbia University in New York, the project is applying a range of poverty-slashing interventions to 12 sites across Africa (see map). The idea is not just to show that interventions in a number of different areas, properly coordinated and financed, can make a sustainable change to the lives of the world's poorest communities. It is to show how that can be done quickly in a way that can be replicated easily.

Donald Ndahiro, an agronomist trained in Uganda, is the project's agriculture coordinator for Rwanda. He says that when he arrived in Kagenge late last year conditions were desperate. "The villagers were emaciated." They wanted food aid more than they wanted the agricultural advice, drought-resistant seeds, fertilizer and new techniques that the project was offering. ${ }^{~}$ They thought we were making fun of them," Ndahiro says. "We were telling them how to plant, how to harvest, but they were saying they were never getting any good rains. We told them to get organized."

Five months later and the villagers are getting organized. Ndahayo is a member of the agriculture committee that will decide what to do with the surplus from this year's corn harvest. Mukaritaganda is helping to clear land for a tree nursery (villagers sometimes walk 


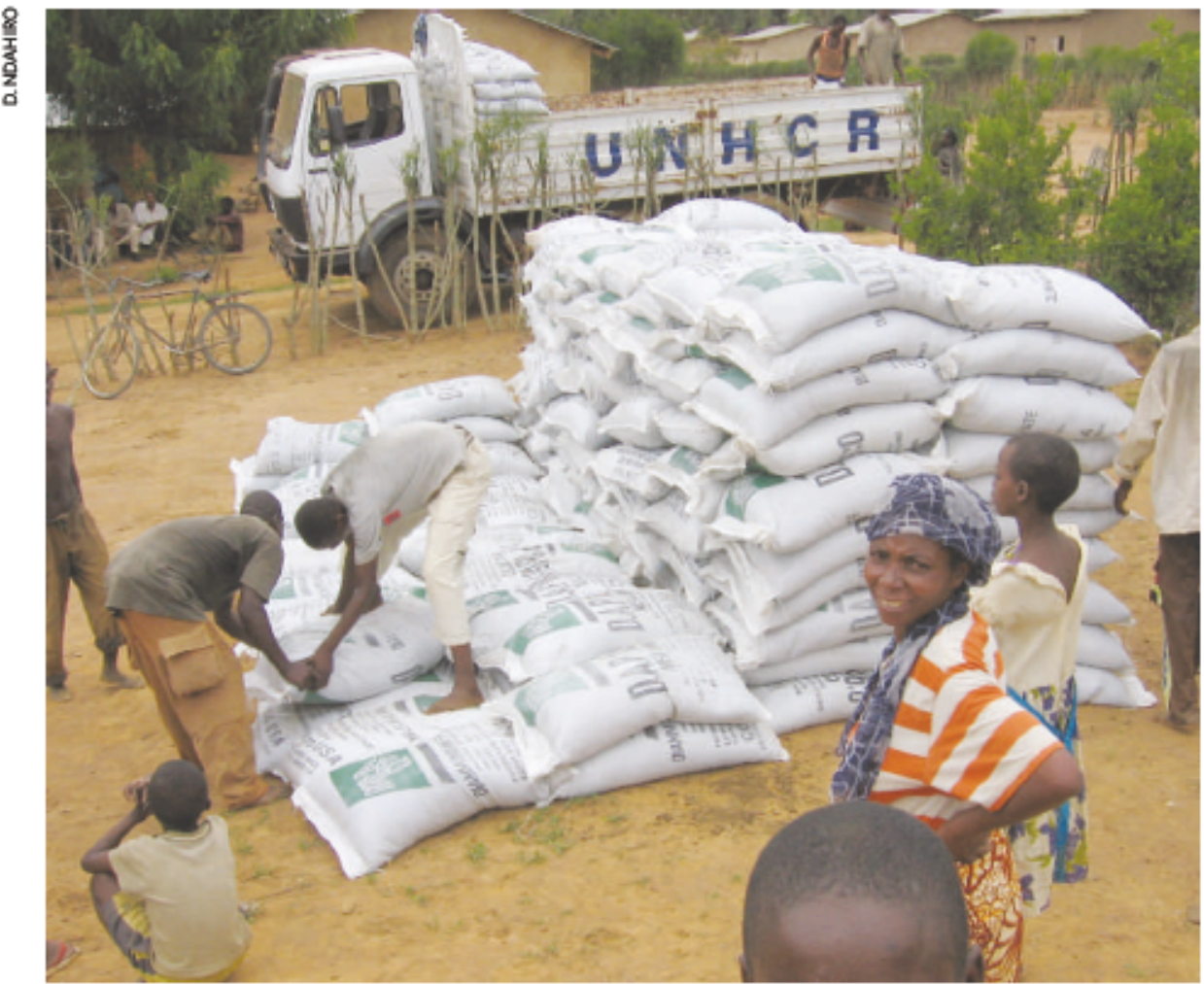

Fertilizer, seeds and advice are being given to 12 villages in Africa, to demonstrate how properly coordinated interventions can make a sustainable difference to people's lives.

ten kilometres to gather firewood) and was part of the team that just built a communal tank to collect rainwater. She invites me with pride to a ceremony in which certificates are awarded to her and the 25 other villagers who worked on the tank.

\section{Leading the way}

The Millennium Villages project aims to provide improved resources and techniques not only in agriculture, but also in health, education, transport, energy and water provision, and financial management. The plan is

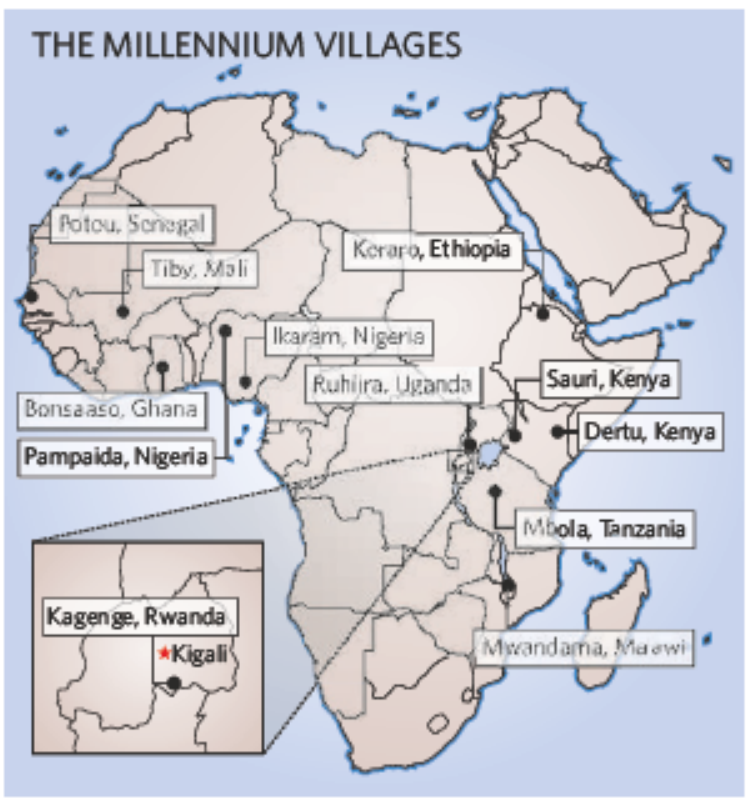

to achieve the United Nations' Millennium Development Goals (see above, right) for the 5,000 or so people in Kagenge, and for the tens of thousands of people in the 11 villages elsewhere within 5 years -5 years ahead of the UN target date.

The eight goals, committed to by 189 heads of state in 2000 , include halving the number of people living on less than US $\$ 1$ a day and controlling malaria by 2015. Progress so far has been limited, especially in Africa - far too slow for the impatient economist Jeffrey Sachs, head of the UN Millennium Project and the Earth Institute. Sachs wants the 'research villages' and the data that they provide to offer ways of picking up the pace: ${ }^{\alpha}$ The idea is to demonstrate a practical path and to mobilize governments."

The man in charge of making such a demonstration is Josh Ruxin, a Columbia University public-health expert and the project's director in Rwanda. Ruxin, imbued with an impressive energy and passion, was initially sceptical of the village-by-village approach: he wanted to target a millennium country not an isolated village. But Ruxin is encouraged by the Rwandan government's own ambitious poverty-reduction strategy, known as Vision 2020.

Ben Karenzi, the Rwandan health ministry's secretary general
MILLENNIUM DEVELOPMENT GOALS

- Eradicate extreme poverty and hunger

- Achieveuniversal primary education

- Promote gender equality and empower women

- Reduce child mortality

- Improvematernal health

- Combat HN and AIDS, malaria and other diseases

- Ensure environmental sustainability

- Develop a global partnership for development

says "We believe it's possible, especially with the focused leadership we have and the commitment of our people, to make Rwanda a midlevel income country by 2020 . In the context of that commitment, Ruxin is confident that with the help of the Millennium Villages project, Rwandans can succeed in not just turning round one village, but in transforming life for poor farmers across the country.

\section{Money cares}

Part of Ruxin's confidence comes from an assessment of the government. In the aftermath of the genocide of 1994 and the resettlement of some two million returnees from neighbouring countries, $64 \%$ of Rwandas population was living in poverty (on less than US $\$ 1$ a day) in 2000 . But despite its internationally criticized role in the Congo war, the government of Paul Kagame is widely seen as committed to poverty reduction, and as embodying principles of good governance from the top down (for example, all ministers are required to declare their annual income).

Ruxin believes that good governance will be an important factor in the long-term success of the millennium villages. Those running the project have deliberately avoided what they see as the worst African regimes. But they say that even in corruption-prone nations, such as Ethiopia and Kenya, the research villages so far remain free of corruption. Sachs points out that if you focus on supplying commodities, such as seeds, fertilizer and nets for protection against malaria, "there's very little money that changes hands". That said, Sachs is less worried than many about corruption; he knows people criticize this lack of concern, but doesn't care. "Corruption is way down the list of practical issues," he argues, Africa's miserable roads, poor soil and endemic disease burden are at the top.

Indeed, the road from Kigali, Rwanda's capital, to Kagenge in the Nyamata district, throws up choking red dust in the dry season and can be impassable in the rainy season. Although the land looks green from the air, the rains can be infrequent and Ndahiro confirms that the soils are poor. Some $70 \%$ of the patients at the villages clinic have malaria and the district has one of the country's highest levels of HIV, at about $13 \%$.

As well as suffering from Sachs's top three 
problems, Kagenge has its own particular sadnesses.

$\checkmark$ The local mayor, Gaspard Musonera, lost three-quarters of his family in the 1994 genocide. "Nyamata district lost more than half of its population," he says. “The implications and consequences of that you can imagine for yourself."

Kagenge itself is a community created since the genocide. Half the households live in settlement housing - or umudugudu - built by the government for survivors and returnees. Ndahiro is himself a returnee, living in Nyamata near the church where 10,000 people were murdered in $1994-$ the blood stains on the walls and altar doth remain as a memorial. He recalls how lifeless the town was when he arrived in 1997. People were bitter, he says; some didn't want to continue living.

\section{Grand plan}

Musonera sees the Millennium Villages project as a sign of hope for the most vulnerable people in his district, and a big test for povertyreduction measures. "If it can be done here, it means it can be done elsewhere, he says and that indeed is the point. The project is not just about breaking the cycle of poverty in 12 villages, but about learning how to do it in 1,200 or 12,000 . Sachs's plan is to show that with a five-year investment of about US\$550 per person $-\$ 50$ a year from the project, $\$ 30$ from government, $\$ 20$ from other donors and $\$ 10$ from the villagers an integrated package of low-cost interventions can produce long-term financial sustainability in a way that not only can be repeated but can also be scaled up. The project plans to grow to 78 villages this year by creating clusters around the 12 original research villages. The expansion is being funded by the US Millennium Promise charity, which has so far raised $\$ 100$ million to support Sachs's vision.

Not everyone is convinced that the Millennium Villages project will succeed. Ecologist Ian Scoones at the Institute of Development Studies at the University of Sussex in Brighton, UK, is a member of the Future Agricultures Consortium, which was put together by the UK Department for International Development to focus on African agriculture and development. Scoones points to the Integrated Rural Development and 'villagization' schemes that tried to boost African agriculture in the
1970 s and 1980s. "They created little islands of success but when donors pulled the plug they all collapsed." Scoones says he is very pleased that the millennium villages are putting African agriculture back on the map, but he is afraid of old mistakes being repeated, and worried about things moving too quickly. "India launched its green revolution in the mid-1960s on the back of decades of solid investment and research," he points out. "It didn't happen overnight."

For his part, Sachs sees patience, like a welldeveloped sensitivity to the issue of corruption, as an overrated virtue. He has no worries about moving too fast. "It happens to be an emergency," he says. And he has no illusions about the projects working as examples simply by word of mouth. "This is not viral. You can't do it without resources," Sachs notes as ambitions grow, so must spending. The biggest risk, he says, is for official donors to sit on their hands.

The goal is not to do without large transfers of money to Africa, it is to work out how to make those transfers more effective. After all, the individual interventions used in the Millennium Villages project are tried and tested methods, even if they haven't been applied all together in one location before. Asked about the target of reaching the millennium goals in five years, Celina Schocken, an international-affairs fellow at the US Council on Foreign Relations, says «I absolutely believe they will succeed. I don't see how they can't."

But she's less convinced about how scale up will be achieved. "What good is an island of prosperity anyway?" she asks. Scoones agrees that the big question is: "How, without that external support, do you replicate?"

That is the question Sachs, Ruxin and their colleagues are trying to answer. By documenting all the inputs and outputs for each research village they hope to tease out the synergies between overlapping interventions. Measuring 35 indicators for the 8 goals across several hundred households in 12 villages is time consuming and costly, but it is necessary to show not just that the investments work, but also how they work, and how they can work better. Only then can they be scaled up to the truly monumental level envisioned by Sachs, who wants to see development aid change the course of history. "I think the

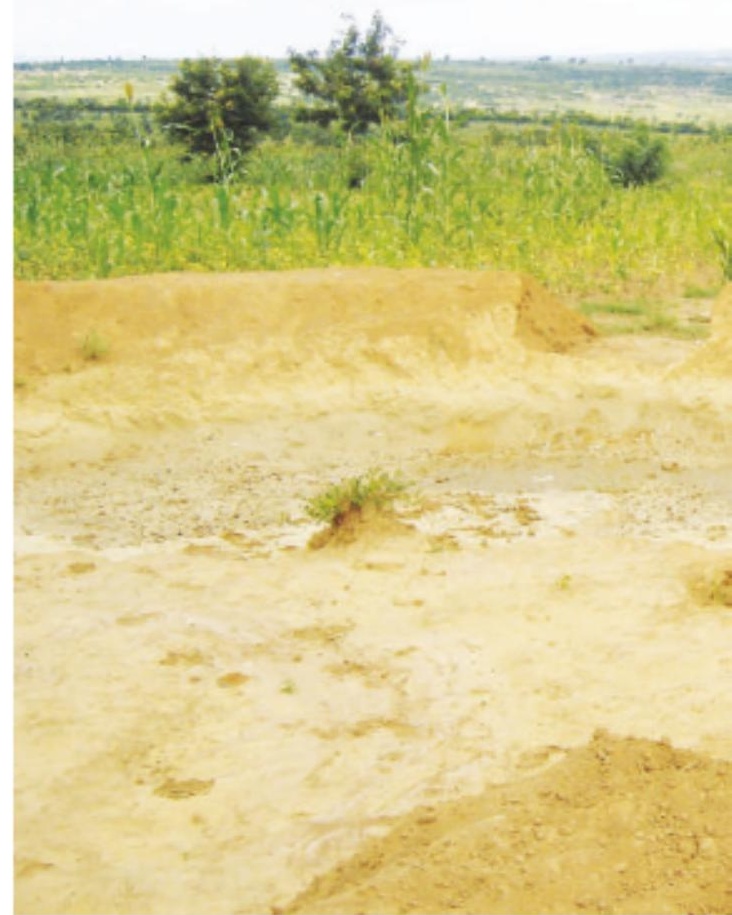

Donald Ndahiro, an agronomist working for the Millennium Villages project, has helped to transform conditions in Kagenge in just five months.

biggest challenge is the defeatist attitude of the official donor community," says Sachs. Such rhetoric reinforces the suspicion that Sachs is unwilling to learn from lessons of the past. "People in the development community see some benefit in the publicity Jeff Sachs gets," says Schocken, who used to work with Ruxin in Rwanda, "but they've seen these ideas before."

\section{Skillshortage}

In Kagenge, the villagers assembled for the water-tank certificate ceremony are briefly reminded of the international debate over their future. "This is an important day for the project," Ruxin tells them during a short address, "You are now the teachers for us and for the world." Some of the farmers I met in the fields yesterday have donned suits and ties for the occasion. Each villager who received training from visiting Kenyan water specialists receives a signed certificate - the expectation is that they will take the skills they have learned and pass them on to others. After many more speeches by village leaders, the villagers distribute soft drinks and, for those who can stomach it, fermented sorghum, the local brew.

In the weeks before the corn is harvested, 
